\title{
Management and relocation of nests of Podocnemis expansa (Schweigger, 1812) (Testudines, Podocnemididae) on the Crixás-Açu River, Brazil
}

\author{
Gomes, AS.* and Ferreira Júnior, PD. \\ Programa de Pós-graduação em Ecologia de Ecossistemas, \\ Centro Universitário Vila Velha - UVV, Rua Comissário José Dantas de Melo, 21, Boa Vista, \\ CEP 29102-770, Vila Velha, ES, Brazil \\ *e-mail: asilgomes@gmail.com \\ Received September 24, 2010 - Accepted December 23, 2010 - Distributed November 30, 2011
}

(With 1 figure)

\begin{abstract}
Podocnemis expansa nests in the sandbanks of the Crixás-Açu River in central Brazil during the dry season. With the return of the rainy season, the river banks are once again inundated, flooding nests and eggs and drowning hatchlings. This study evaluated relocation as an alternative to manage nests at risk of flooding. Forty $P$. expansa nests from four beaches of the Crixás-Açu were relocated to nurseries constructed in tanks filled with sand from the same river. Nine nests were covered with palm fronds to simulate shading conditions and to lower the incubation temperature. The base of the egg chamber was at a depth of $60 \mathrm{~cm}$ in all the nests. The duration of incubation varied for sunlit $(49.1 \pm 2.35$ days) and shaded nests $(51.7 \pm 1.75$ days $)$, but did not change with nest position (center or edge of nurseries). Hatching success was $47.3 \pm 13.6 \%$, and did not vary significantly with sunlight/shade or nest position. The mean incubation temperature during the thermosensitivity period varied from $33 \pm 1.56{ }^{\circ} \mathrm{C}$ to $34.1 \pm 1.40{ }^{\circ} \mathrm{C}$. The lowest mean temperature during the thermosensitivity period $\left(31.9 \pm 0.95^{\circ} \mathrm{C}\right.$ ) and the highest proportion of males (up to $45 \%$ of hatchlings) were observed in a shaded nest. Most sunlit nests produced only females. The results suggest that relocation is a viable alternative in managing nests at risk of flooding during the rainy season in the Crixás-Açu. Moreover, artificial shading was shown to be an option to increase the proportion of males.
\end{abstract}

Keywords: hatching, incubation, nursery, sex ratio, giant Amazon River turtle.

\section{Manejo e transferência de ninhos de Podocnemis expansa (Schweigger 1812) (Testudines, Podocnemididae) no Rio Crixás-Açu, Brasil}

\begin{abstract}
Resumo
Durante o período de maior vazante do rio Crixás-Açu na região central do Brasil, nos meses de setembro e outubro, Podocnemis expansa (tartaruga-da-amazônia) desova nos bancos arenosos que surgem nas suas margens. Com o retorno do período chuvoso em novembro é comum que as praias deste rio sejam inundadas afogando ovos e filhotes. Este trabalho avalia a transferência como alternativa de manejo dos ninhos que seriam naturalmente alagados. Foram transferidos 40 ninhos de $P$. expansa oriundos de quatro praias do rio Crixás-Açu para berçários construídos em tanques de alvenaria que foram preenchidos com areia oriunda do próprio rio. Nove ninhos foram cobertos com folhas de palmeira para simular o sombreamento e diminuir a temperatura da incubação. A base da câmara de ovos de todos os ninhos situou-se a $60 \mathrm{~cm}$ de profundidade. A duração de incubação variou entre os ninhos ensolarados $(49,1 \pm 2,35$ dias $)$ e ninhos sombreados $(51,7 \pm 1,75$ dias $)$, mas não foi afetada pela posição do ninho, se nas bordas ou no centro dos berçários. O sucesso da eclosão foi de 47,3 $\pm 13,6 \%$ e não foi afetado pelo sombreamento ou pela posição do ninho nos berçários. A temperatura média de incubação durante o período termossensitivo variou de $33 \pm 1,56{ }^{\circ} \mathrm{C}$ a $34,1 \pm 1,40{ }^{\circ} \mathrm{C}$. Os ninhos ensolarados produziram $100 \%$ de fêmeas em sua maioria. Os resultados mostram que a transferência é uma alternativa viável para o manejo dos ninhos que seriam alagados durante as cheias do rio Crixás-Açu e o sombreamento artificial dos ninhos é uma alternativa para aumentar a produção de machos nos berçários.
\end{abstract}

Palavras-chave: eclosão, incubação, berçário, razão sexual, tartaruga-da-amazônia. 


\section{Introduction}

Sex determination of the giant Amazon river turtle Podocnemis expansa (Schweigger, 1812, Podocnemididae) depends on the egg incubation temperature (Alho et al., 1984; Valenzuela et al., 1997; Malvasio et al., 2002a,b. The nesting environment, as well as its physical and climatic characteristics determine the temperature inside nests, which reveals the crucial importance of choosing appropriate oviposition sites to the reproductive success of the species (Ferreira Júnior, 2009). The reproductive cycle of Podocnemis and hydrological cycles are synchronously related. During the period of receding water, sandy beaches are formed on the riverbanks. These beaches are utilized as nesting areas by $P$. expansa (Alho and Pádua, 1982), P. unifilis Troschel (Ferreira Júnior and Castro, 2010), P. sextuberculata Cornalia (Pezzuti and Vogt, 1999), P. lewyana Duméril (Correa et al., 2010), and P. erytrocephala Spix (Batistella and Vogt, 2008). In the search for the most suitable beaches for nesting, females must choose sites that are topographically high enough to prevent the flooding of nests at the start of the rainy season. Moreover, the temperatures in these environments must be suitable to allow complete embryo development and promote sex ratios that ensure the species' population levels (Valenzuela et al., 1997).

The reproduction of $P$. expansa is affected by the climatic conditions of the west-central region of Brazil. For example, when the rainy season starts earlier than usual, sudden rises in water level, locally called repiquete, may be caused by rains in the headwater regions. This phenomenon causes the beaches to flood and results in the drowning of embryos (Alho and Pádua, 1982; Mitchell and Quiñones, 1994). In the Crixás-Açú River basin, this phenomenon is quite common, and is the main cause of losses of $P$. expansa nests (Ferreira Júnior and Castro, 2006b). In order to reduce the potential loss of large numbers of hatchlings, RAN/ICMBio (Reptile and Amphibian Conservation and Management Center, an organization that has formed a partnership with the Brazilian Institute of the Environment and Natural Renewable Resources) recommends the relocation of nests to topographically higher sites. However, simply raising the level of the nests on a beach is not the only aspect to consider. Equally important is the choice of an appropriate site to ensure that the temperature inside relocated nests matches that of the original nests. This must be considered in nest relocations, since the differences in grain size (Ferreira Júnior et al., 2003) and mineral composition of sediments (Milton et al., 1997; Naro-Maciel et al., 1999) may substantially change the nest's heat-transfer regimen (Ferreira Júnior and Castro, 2006b), affecting sex determination of embryos. In nest relocations, the new nesting site should provide the appropriate conditions to produce a sex ratio that is similar to that observed in natural nests (Tuttle and Rostal, 2010).

Knowing the sex ratio of embryos born in a natural environment is an essential element in management and conservation projects for species with temperature-dependent sex determination (Morreale et al., 1982; Girondot et al., 1998). In turn, understanding how a given physical trait influences nest temperature is important to elucidate the factors that influence sex determination of $P$. expansa. This knowledge is useful in the charting of areas expected to be appropriate for the relocation of nests, and in the establishment of conservation areas and environmental management practices. The present study evaluated the role of incubation site features in a pattern of temperature variation in relocated nests of $P$. expansa.

\section{Materials and Methods}

Eggs of Podocnemis expansa were collected in four beaches located near the outpost of RAN/ICMBio on the Crixás-Açú River ( $13^{\circ} 03^{\prime} 10^{\prime \prime} \mathrm{S}$ and $50^{\circ} 14^{\prime} 27^{\prime}$ 'W), located in the municipality of Nova Crixás, state of Goiás, Brazil. During the incubation period of $P$. expansa, flooding of beaches is common in the region, killing the hatchlings and embryos. A more detailed description of the beaches of the Crixás-Açu was given by Ferreira Júnior and Castro (2006b). In order to minimize the effects caused by collection, transport, and handling of eggs (Malvasio et al., 2005), only recent nests (up to two days old) were selected. Eggs were stored in styrofoam boxes filled with sand from the inner nest. This procedure was adopted to maintain the nest temperature and humidity, as well as to prevent the eggs from shaking and rotating during translocation.

Two brick and mortar tanks, originally built to be used in experiments with the breeding of $P$. expansa in captivity, were used as nurseries. The $60 \mathrm{~m}^{3}(\mathrm{~W}=3 \mathrm{~m} ; \mathrm{L}=10 \mathrm{~m}$; $\mathrm{H}=2 \mathrm{~m}$ ) tanks were filled with sand from the Crixás-Açu beaches one day before the beginning of the relocations. For this reason, the sediment was not quite compact, which made it necessary to use a PVC tube $(25 \mathrm{~cm}$ in diameter) to assist in the digging and compaction of the walls of the egg chamber. When eggs were placed in the nest, the tube was removed carefully, avoiding moving and rotating the eggs. The distance between nests was $40 \mathrm{~cm}$, and the base of the egg chamber was $60 \mathrm{~cm}$ deep (the same interval and size of nests in the natural environment, according to Ferreira Júnior and Castro, 2003). Rainfall data were obtained from the National Hydrological Information System (Hidroweb) from the Brazilian Water Management Agency (ANA), collected at the gauge station located in São Miguel do Araguaia, nearly $50 \mathrm{~km}$ distant from the nursery. Thirty-one nests relocated to the nursery were exposed to sunlight throughout the incubation period. Nine other nests were shaded, covered with fronds of a palm tree (Cocos nucifera L.), to observe the influence of shading on the nest temperature and on the hatchling sex ratio. Samples of sand from the inner sediments of 26 nests were collected for grain size analysis. The temperature of seven nests was monitored using digital thermographs (Novus, Termotag), inserted in the middle of the egg chamber, and recorded every 15 minutes during the incubation period. The thermographs were distributed 
in nests located in the center and along the edge of the nurseries to assess the influence of the concrete walls on heat distribution. If the nest's surface caved in, the nest was dug out. The numbers of living hatchlings, of dead hatchlings (animals that exited the egg but died in the nest), of retained hatchlings (animals that broke the eggshell but died before leaving the egg completely), and number of unhatched eggs were recorded. These data were used to calculate hatching success, here defined as the ratio of the number of living hatchlings to the total number of eggs. The duration of incubation was calculated as the number of days elapsed between oviposition and nest opening.

The sex of the turtles was identified based on the histological gonad analysis of 70 hatchlings from nests where the temperature was measured. Ten hatchlings were taken at random from each nest to determine the sex and calculate the sex ratio. The specimens were euthanized with $25 \%$ sodium thiopental injected intracardially. Slides were stained with hematoxylin-eosin and inspected in an optical microscope. Ovaries and testes were differentiated according to the criteria defined by Malvasio et al. (2002a).

Sediment grain size was established using eight fractions, according to the classification of Folk. Granulometric analysis was conducted by sieving, and the percentage of

Table 1. Variation in incubation duration, hatching success, and grain size in terms of the degree of shading and position of 26 nests of Podocnemis expansa in nurseries along the Crixás-Açu River.

\begin{tabular}{lccccc}
\hline \multirow{2}{*}{\multicolumn{1}{c}{ Parameter }} & \multicolumn{2}{c}{$\begin{array}{c}\text { Shading } \\
\text { intensity }\end{array}$} & & \multicolumn{2}{c}{ Nest position } \\
\cline { 2 - 3 } \cline { 6 - 6 } & $\mathbf{H}$ & $\mathbf{p}$ & & $\mathbf{H}$ & $\mathbf{p}$ \\
\hline Incubation duration & 9.27 & 0.004 & & 0.893 & 0.345 \\
Hatching success & 0.16 & 0.691 & & 1.021 & 0.281 \\
Grain size & & & & & \\
$\quad$ Gravel & 1.252 & 0.274 & & 1.102 & 0.304 \\
Granule & 1.136 & 0.286 & & 0.114 & 0.736 \\
Very coarse sand & 0.611 & 0.434 & & 2.037 & 0.154 \\
Coarse sand & 0.08 & 0.776 & & 1.488 & 0.223 \\
$\quad$ Medium sand & 0.854 & 0.356 & & 3.788 & 0.052 \\
$\quad$ Fine sand & 0.505 & 0.477 & & 3.589 & 0.058 \\
Very fine sand & 1.192 & 0.286 & & 0.421 & 0.517 \\
\hline
\end{tabular}

each grain size class was arcsine-transformed to normalize the data. Variation in incubation duration, hatching success, and grain size between shaded and sunlit nests in the center and in the border of nurseries was assessed using the Kruskal-Wallis test at the 5\% significance level. The influence of grain size on the duration of incubation and on hatching success was tested using multiple linear regression. Because of the high colinearity of data, some granulometric fractions were excluded from the calculations. Hatching success was arcsine-transformed to normalize data. These tests were conducted using the Statistica 6.0 software. The null hypothesis that the mean temperature during the thermosensitivity period did not affect hatching of males and females was tested using the binary logistic regression (Hosmer and Lemershow, 2000) in MINITAB 13.0.

\section{Results}

Grain size did not vary between shaded and sunlit nests, irrespective of nest position (edge or center of nurseries) (Table 1). All samples analyzed were classified as "gravelly sand" (sensu Folk and Ward, 1957), with a prevalence of coarse sand fractions (Table 2). The mean duration of incubation was longer in the shaded nests $(51.7 \pm 1.75$ days $)$ compared to the sunlit nests $(49.1 \pm 2.35$ days $)$, though it was not affected by the position of the nest in the nurseries (Table 3). The mean hatching success was $47.3 \pm 13.6 \%$ (ranging between 11.97 and $73.53 \%$ ), and was not affected by the degree of shading or the position of the nest in the nursery (Table 3). Grain size and clutch size did not influence the incubation duration and hatching success of $P$. expansa (Table 4). The number of retained hatchlings $(26.7 \pm 17.43 \%)$ was higher than the number of hatchlings that died inside the nests $(1.2 \pm 2.7 \%)$. The proportion of retained hatchlings reached $44 \%$, while the highest proportion of dead specimens was $13.7 \%$. A considerable number of specimens had "folded" carapaces and plastrons, although these animals did not show any irregular scute pattern.

The percentage of females varied between $55 \%$ (in shaded nests) and $100 \%$ (in sunlit nests) (Table 3). The temperature of monitored nests increased in the incubation period, though with two sharp drops that signalled the beginning of the second third of the incubation period (Table 4 and Figure 1). These drops were associated with

Table 2. Grain size distribution of sediments of nests of Podocnemis expansa monitored using thermographs (percent values), along the Crixás-Açu River.

\begin{tabular}{ccccc}
\hline Nest & Very coarse sand & Coarse sand & Medium sand & Fine sand \\
\hline 18 & 9.49 & 17.82 & 40.73 & 21.48 \\
22 & 20.12 & 41.61 & 26.7 & 3.82 \\
26 & 19.22 & 40.95 & 25.64 & 3.18 \\
33 & 20.3 & 45.34 & 23.41 & 3.05 \\
36 & 6.59 & 16.49 & 43.37 & 26.09 \\
39 & 20.44 & 41.92 & 23.98 & 3.94 \\
45 & 21.51 & 46.31 & 21.92 & 2.79 \\
\hline
\end{tabular}


Table 3. Incubation temperature, sex ratio, hatching success and incubation duration in relocated P. expansa nests.

\begin{tabular}{ccccccc}
\hline $\begin{array}{c}\text { Mean } \\
\text { temperature } \\
\left({ }^{\circ} \mathbf{C}\right)\end{array}$ & $\begin{array}{c}\text { Mean } \\
\text { temperature } \mathbf{2 / 3} \\
\left({ }^{\circ} \mathbf{C}\right)\end{array}$ & $\begin{array}{c}\text { Temperature } \\
\text { range } \\
\left({ }^{\circ} \mathbf{C}\right)\end{array}$ & $\begin{array}{c}\text { Females } \\
(\boldsymbol{\%})\end{array}$ & $\begin{array}{c}\text { Incubation } \\
\text { duration } \\
(\mathbf{D a y s})\end{array}$ & $\begin{array}{c}\text { Hatching } \\
\text { success } \\
(\boldsymbol{\%})\end{array}$ & $\begin{array}{c}\text { Clutch } \\
\text { size }\end{array}$ \\
\hline $34 \pm 1.73$ & $33.5 \pm 1.37$ & $6.9(30.1-37)$ & 100 & 48 & 51.46 & 130 \\
$33.7 \pm 1.63$ & $32.9 \pm 1.0$ & $5.7(31-36.7)$ & 100 & 51 & 55.34 & 103 \\
$34.1 \pm 1.67$ & $33.2 \pm 1.18$ & $5.9(31.4-37.3)$ & 100 & 51 & 43.47 & 114 \\
$33.9 \pm 1.37$ & $33.2 \pm 1.08$ & $5.1(31.5-36)$ & 100 & 49 & 47.71 & 109 \\
$34.1 \pm 1.40$ & $33.5 \pm 1.22$ & $5.5(31.4-36.9)$ & 100 & 48 & 49.46 & 93 \\
$33 \pm 1.56$ & $31.9 \pm 0.95$ & $6.2(29.6-35.8)$ & 73 & 49 & 54.74 & 95 \\
$34.0 \pm 1.79$ & $33.2 \pm 1.12$ & $7(30.4-37.4)$ & 90 & 48 & 32.81 & 128 \\
\hline
\end{tabular}

Table 4. Influence of grain size and number of eggs on incubation duration and hatching success of 26 relocated nests of Podocnemis expansa from the Crixás-Açu River. Because of high colinearity (hc), some grain size fractions were excluded from correlations. Results are expressed as mean \pm standard deviation.

\begin{tabular}{lcccccc}
\hline \multirow{2}{*}{ Variable } & \multirow{2}{*}{ Mean } & \multicolumn{2}{c}{ Incubation duration } & & \multicolumn{2}{c}{ Hatching success } \\
\cline { 3 - 4 } \cline { 6 - 7 } & & $\mathbf{t}$ & $\mathbf{p}$ & & $\mathbf{t}$ & $\mathbf{p}$ \\
\hline Incubation duration (Days) & $49.1 \pm 2.35$ & & & & -0.287 & 0.777 \\
Number of hatchlings & $104.6 \pm 23.05$ & -1.453 & 0.162 & & -1.053 & 0.305 \\
$\quad$ & & & & & & \\
$\quad$ Grain size & $2.02 \pm 1.06$ & -0.86 & 0.401 & & 0.749 & 0.463 \\
Gravel & $5.9 \pm 2.52$ & 1.572 & 0.132 & & 1.084 & 0.291 \\
Granule & $18.8 \pm 4.12$ & 0.384 & 0.705 & & hc & hc \\
$\quad$ Very coarse sand & $40.5 \pm 7.98$ & hc & hc & & hc & hc \\
Coarse sand & $26.7 \pm 6.45$ & hc & hc & & hc & hc \\
Medium sand & $5.2 \pm 5.99$ & hc & hc & & 0.373 & 0.713 \\
Fine sand & $0.76 \pm 0.17$ & 0.801 & 0.433 & & -0.226 & 0.824 \\
$\quad$ Very fine sand & & & & &
\end{tabular}

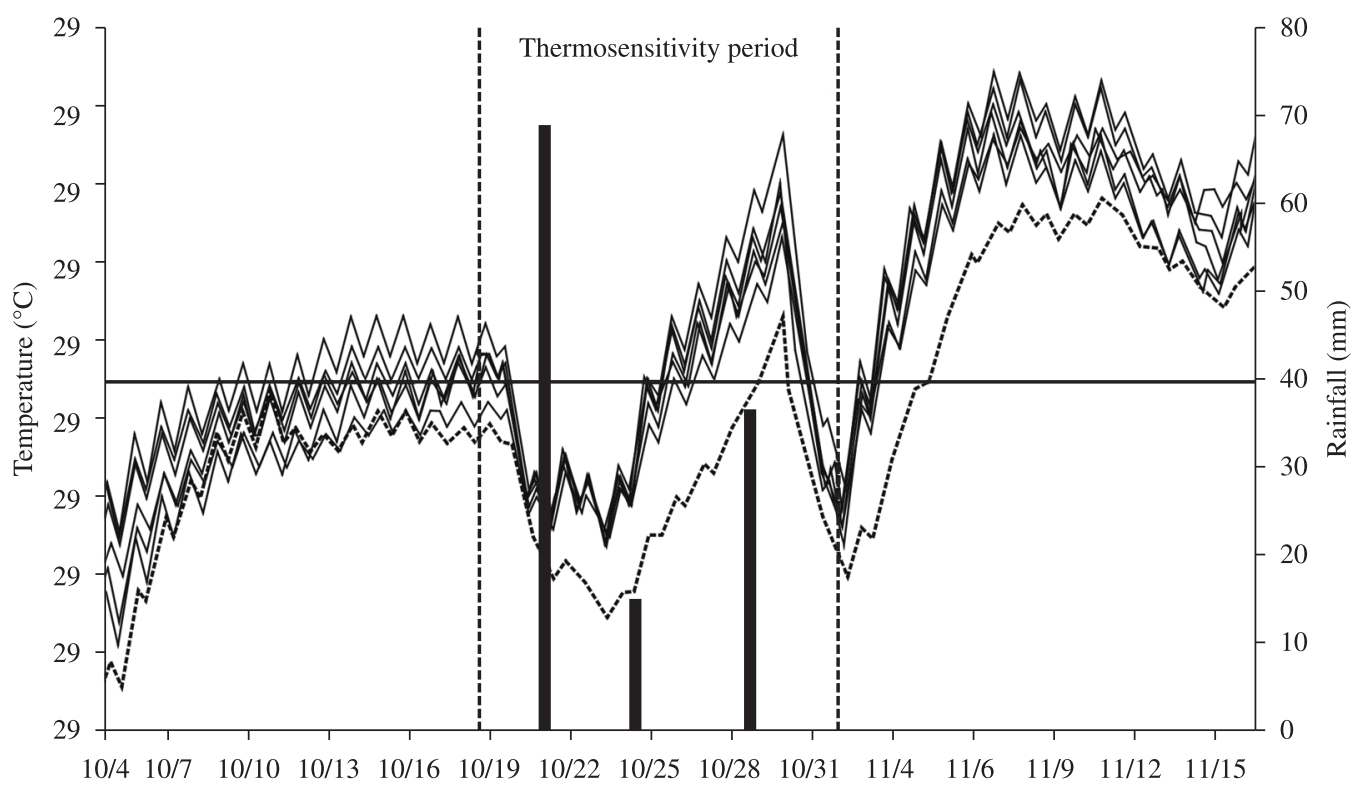

Figure 1. Daily variation of temperature inside nests and of rainfall in the region of the Crixás-Açu River, in October. The temperature dotted line is from a shaded nest. The horizontal line in the center indicates the pivotal temperature of Podocnemis expansa for the population inhabiting the Javaés River (Lubiana and Ferreira Júnior, 2009). 
the rains during these two periods. The rainfall reached $68.8 \mathrm{~mm}$ on a single day in October, when the first drop in temperature was observed. The rainy season started between mid-October and mid-November, with an eventual total rainfall of $284.3 \mathrm{~mm}$.

The mean temperature of nests during incubation varied between $33 \pm 1.56{ }^{\circ} \mathrm{C}$ and $34.1 \pm 1.4{ }^{\circ} \mathrm{C}$. During the thermosensitivity period of sex determination, the second third of the incubation period (Bull and Vogt, 1981), nest temperature varied between $31.9 \pm 0.95^{\circ} \mathrm{C}$ and $33.5 \pm 1.37^{\circ} \mathrm{C}$. These values were above the pivotal temperature, except in shaded nests where temperatures were lower, leading to a higher production of males (Figure 1). The lowest mean temperature in the second third of the incubation period $\left(31.9^{\circ} \mathrm{C}\right)$ was observed in a shaded nest. Incubation temperature was responsible for the sex ratio observed. The risk rate in the binary logistic regression showed that the mean incubation temperature provides a more cogent explanation for the female-biased sex ratio, than the mean temperature during the second third of the incubation period (Table 5). The peaks in the beginning of the second third of the incubation period reduced the mean temperature in the interval, making it lower than the mean temperature measured for the entire incubation period.

\section{Discussion}

The sand used in this experiment was dug from a single location in a beach of the Cixás-Açú River, which explains why grain size did not vary across the different nests in the nurseries, as occurs in nests that turtles dig along the nesting beaches (Ferreira Júnior and Castro, 2003; 2005). Since nests were transferred one day after the sand was placed in the nursery, there was no time for this sediment to compact. Bjordnal and Bolten (1992) stated that the walls of the egg chamber normally collapse in beaches where the sediment is drier and less compacted, which eventually decreases hatching success of Chelonia mydas (Linnaeus). The gradual and progressive compaction of sand during incubation reduces empty spaces in the egg chamber, compressing the eggs and hindering embryo development. This compaction of sand is the reason for the irregular or folded shell of hatchlings, and although it caused neither malformation nor defects in scute patterns (Malvasio et al., 2005; Salera Júnior et al., 2009), it restricted the movement of hatchlings of $P$. expansa. Also, sand compaction was an obstacle to hatchlings retained in the eggs, since the effect decreased the space available inside the egg chamber. Temperatures above $36{ }^{\circ} \mathrm{C}$ and below $28{ }^{\circ} \mathrm{C}$ reduce the survival rates of $P$. expansa embryos (Valenzuela et al., 1997; Lubiana and Ferreira Júnior, 2009). In our study, temperatures inside the nests exceeded $35.8^{\circ} \mathrm{C}$, reaching $37.4{ }^{\circ} \mathrm{C}$ in nest 39 , which remained exposed to sunlight throughout the incubation period. Of the seven nests where temperatures were monitored, nest 39 showed the lowest hatching success, indicating that the high temperatures increased the death rate of the embryos and hatchlings.

The incubation temperature of $P$. expansa is high, since the species' distribution is limited to tropical regions (Pritchard and Trebbau, 1984; Rueda-Almonacid et al., 2007). Furthermore, females of this species typically choose sandy, sunlit beaches without vegetation to nest

Table 5. Binary logistic regression between incubation temperature and hatchling sex ratio of Podocnemis expansa from the Crixás-Açu River.

\begin{tabular}{|c|c|c|c|c|c|c|c|}
\hline \multirow{2}{*}{ Models } & \multirow{2}{*}{ Coefficient } & \multirow{2}{*}{$\begin{array}{c}\text { Standard } \\
\text { error }\end{array}$} & \multirow{2}{*}{$\mathbf{Z}$} & \multirow{2}{*}{$\mathbf{p}$} & \multicolumn{3}{|c|}{ Risk rate and limits $(95 \%)$} \\
\hline & & & & & Rate & Low & High \\
\hline \multicolumn{8}{|l|}{ Female } \\
\hline Constant & -63.1 & 31.93 & -1.98 & 0.048 & & & \\
\hline Temp. second third & 2.02 & 0.985 & 2.05 & 0.04 & 7.56 & 1.09 & 52.13 \\
\hline \multicolumn{8}{|c|}{$\mathrm{G}=4.616 ; \mathrm{p}=0.032 ; \mathrm{gl}=1 ;$ Hosmer $x^{2}=0.963 ; \mathrm{p}=0.618 ; \mathrm{df}=2$} \\
\hline \multicolumn{8}{|l|}{ Female } \\
\hline Constant & -87.4 & 44.96 & -1.94 & 0.052 & & & \\
\hline Mean temperature & 2.69 & 1.347 & 2 & 0.046 & 14.78 & 1.05 & 207.2 \\
\hline \multicolumn{8}{|c|}{$\mathrm{G}=4.24 ; \mathrm{p}=0.039 ; \mathrm{df}=1 ;$ Hosmer $x^{2}=2.35 ; \mathrm{p}=0.503 ; \mathrm{df}=3$} \\
\hline \multicolumn{8}{|c|}{${ }^{2}$} \\
\hline Constant & 63.1 & 31.9 & 1.98 & 0.048 & & & \\
\hline Temp. second third & -2.02 & 0.985 & -2.05 & 0.04 & 0.13 & 0.02 & 0.91 \\
\hline \multicolumn{8}{|c|}{$\mathrm{G}=4.61 ; \mathrm{p}=0.032 ; \mathrm{gl}=1 ;$ Hosmer $x^{2}=2.349 ; \mathrm{p}=0.503 ; \mathrm{gl}=3$} \\
\hline \multicolumn{8}{|c|}{ 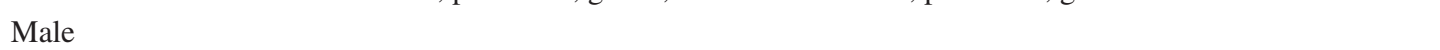 } \\
\hline Constant & -4.8 & 0.43 & -11.04 & 0 & & & \\
\hline Mean temperature & 49.68 & 1.347 & -2 & 0.046 & 0.07 & 0 & 0.95 \\
\hline \multicolumn{8}{|c|}{$\mathrm{G}=4.24 ; \mathrm{p}=0.039 ; \mathrm{df}=1 ;$ Hosmer $x^{2}=0.963 ; \mathrm{p}=0.618 ; \mathrm{df}=2$} \\
\hline
\end{tabular}

Z) standardized value of the coefficient according to the reduced normal curve; p) level of significance, $*$ significant test; df) degrees of freedom. 
(Alho et al., 1984; Ferreria Júnior and Castro, 2003). The environmental characteristics of the areas where $P$. expansa chooses to nest have led the species to develop a higher pivotal temperature, compared to other reptiles (Valenzuela and Lance, 2004). Experiments conducted in the laboratory under constant incubation temperatures indicate that the pivotal temperature is above $32.6{ }^{\circ} \mathrm{C}$ for the species living in the Caquetá River, Colombia (Valenzuela, 2001), and $33.5^{\circ} \mathrm{C}$ for the turtles inhabiting the Javaés River, state of Tocantins, Brazil (Lubiana and Ferreira Júnior, 2009). The pivotal temperature was estimated as $34.5^{\circ} \mathrm{C}$ in nests in the Trombetas River, state of Pará, Brazil (Alho et al., 1984). In a natural scenario, where temperatures oscillate daily, the mean incubation temperature is not a good prediction factor for sex determination (Georges et al., 1994; Valenzuela et al., 1997; Valenzuela, 2001). In addition, the sex ratio is influenced by oscillations in the pivotal temperature, since the rate of embryo development is directly correlated with incubation temperature (Bull and Vogt, 1981; Mrosovsky et al., 1984, 2009; Marcovaldi et al., 1997). Due to the daily oscillations in temperature, eggs may be exposed to temperatures either below or above the pivotal value, and the length of time that temperatures remain at a certain level will define the embryo's sex (Georges et al., 1994). When the incubation temperature is above the pivotal temperature, the embryo develops more quickly, with a higher proportion of females - even when the mean final temperature is near the pivotal temperature (Bull and Vogt, 1981; Pieau and Dorizzi, 1981; Mrosovsky et al., 1984, 2009; Marcovaldi et al., 1997).

In the present study, the mean temperatures of relocated nests were near the pivotal temperature of $P$. expansa as observed in the Javaés River (Lubiana and Ferreira Júnior, 2009). Similar climate conditions can be found in the Crixás-Açu River and Javaés River regions, which suggests a pivotal temperature of around $33.5^{\circ} \mathrm{C}$ for the turtle population in the former. Our data demonstrate that although the mean temperatures were around the pivotal temperature, the eggs were exposed to temperatures above $33.5^{\circ} \mathrm{C}$, which led to the evolution of a sex ratio biased towards females. Male hatchlings were observed mainly in shaded nests, which also had milder temperatures in the nursery. Shading of nests caused the incubation temperature to drop and increased the incidence of males, as also reported by Alho et al. (1984) and Valenzuela (2001).

The second fortnight of October marked the beginning of the rainy season, with rainfall reaching $284.3 \mathrm{~mm}$, sufficient to raise the river level and flood part of the beaches, drowning thousands of hatchlings and embryos (Ferreira Júnior and Castro, 2006a). Therefore, the results obtained in the present study demonstrate that the relocation of nests exposed to flooding is a feasible alternative for environmental management of the local population of $P$. expansa. However, the observed high percentage of females may lead to an imbalance in the sex ratio. Therefore, shading the nests is recommended in order to increase the number of males produced. Further studies on the population structure of P. expansa of the Crixás-Açu River should be conducted, mainly to evaluate the species' sex ratio. Apart from this, the results obtained in the present study point to the need to develop new alternatives to reduce nest temperature and to increase hatching success in relocated nests. The use of denser, more compact sand may reduce the losses caused by the sliding of egg-chamber walls and minimize the compression of eggs and embryos, thus contributing to higher hatching success rates and decreasing the incidence of folds in hatchlings' shells.

Acknowledgements - The authors are indebted to RAN/ICMBio and to the regional coordination board of the Environmental Conservation Area Meandros do Rio Araguaia, especially to W. Cambuim, for support and assistance, and for the infrastructure made available to conduct this study. We would like to thank L.A.S. Antunes and M.A. Wolkart for their assistance in data collection. Thanks also to the Centro Universitário Vila Velha and to Roberto Carlos, for helping to prepare the slides, and to A. Lubiana for assistance in sexing hatchlings. The authors are grateful to Divino, A.P.G. Lustosa, and N.A. Gomes, for their essential help in the fieldwork stage, assisting in data collection.

\section{References}

ALHO, CJR. and PÁDUA LFM., 1982. Reprodutive parameters and nesting behaviour of the Amazon turtle Podocnemis expansa (Testudinata: Pelomedusidae) in Brazil. Canadian Journal of Zoology, vol. 60, p. 97-103. http://dx.doi.org/10.1139/z82-012

ALHO, CJR., DANNI, TMS. and PÁDUA LFM., 1984 Influência da temperatura de incubação na determinação do sexo da tartarugada-amazônia Podocnemis expansa (Testudinata: Pelomedusidae). Revista Brasileira de Biologia = Brazilian Journal of Biology, vol. 44, n. 3, p. 305-311.

BATISTELLA, AM. and VOGT, RC., 2008. Nesting ecology of Podocnemis erythrocephala (Testudines, Podocnemididae) of the Rio Negro, Amazonas, Brazil. Chelonian Conservation and Biology, vol. 7, n. 1, p. 12-20. http://dx.doi.org/10.2744/ CCB-0611.1

BJORDNAL, KA. and BOLTEN AB., 1992. Spatial distribution of green turtle (Chelonia mydas) nest at Tortuguero, Costa Rica. Copeia, vol. 1992, n. 1, p. 45-53.

BRODERICK, AC., GODLEY, BJ., RESSE, S. and DOWNIE, JR., 2000. Incubation periods and sex ratios of the green turtles: highly female biased hatchling production in the eastern Mediterranean. Marine Ecology Progress Series, vol. 202, p. 273-281 (August). http://dx.doi.org/10.3354/meps202273

BULL, JJ. and VOGT, RC., 1981. Temperature-sensitive periods of sex determination in Emydid turtles. Journal of Experimental Zoology, vol. 218, n. 3, p. 435-440. PMid:7338727. http://dx.doi. org/10.1002/jez.1402180315

CORREA, JCH., CANO-CASTAÑO, AM., PAEZ, VP. and RESTREPO, A., 2010. Reproductive ecology of the Magdalena River Turtle (Podocnemis lewyana) in the Mompos Depression, Colombia. Chelonian Conservation and Biology, vol. 9, n. 1, p. 70-78. http://dx.doi.org/10.2744/CCB-0784.1

FERREIRA JÚNIOR, PD., 2009. Aspectos ecológicos da determinação sexual em tartarugas. Acta Amazonica, vol. 39, n. 1, p. $139-154$. 
FERREIRA JÚNIOR, PD. and CASTRO, PTA., 2003. Geological control of Podocnemis expansa and Podocnemis unifilis nesting areas in Rio Javaés, Bananal Island, Brazil. Acta Amazonica, vol. 33, n. 3, p. 445-468.

-, 2005. Nest placement of giant Amazon river turtle, Podocnemis expansa, in the Araguaia River, Goiás state, Brazil. Ambio, vol. 34 , n. 3, p.212-217

,$- 2006 \mathrm{a}$. Geological characteristics of the nesting areas of the Amazon turtle (Podocnemis expansa) in the Crixás-Açu River in Goiás State, Brazil. Acta Amazonica, vol. 36, n. 2, p. 249-258. http://dx.doi.org/10.1590/S0044-59672006000200015

-, 2006b. Thermal environment characteristics of Podocnemis expansa and Podocnemis unifilis nesting areas on the Javaés River, Tocantins, Brazil. Chelonian Conservation and Biology, vol. 5, n. 1, p. 102-107. http://dx.doi.org/10.2744/1071-8443(2006)5[102:TECOPE]2.0.CO;2

-, 2010. Nesting ecology of Podocnemis expansa (Schweigger, 1812) and Podocnemis unifilis (Troschel, 1848) (Testudines, Podocnemididae) in the Javaés River, Brazil. Brazilian Journal of Biology, vol. 70, n. 1, p. 85-94. http://dx.doi.org/10.1590/ S1519-69842010000100012

FOLK, RK. and WARD, WC., 1957. Brazos River Bar: A study in the significance of grain size parameters. Journal of. Sedimentary Petrology, vol. 27, n. 1, p. 3-26.

GEORGES, A., LIMPUS, C. and STOUTJESDIJK, R., 1994. Hatchling sex in the marine turtle Caretta caretta is determined by proportion of development at a temperature, not daily duration of exposure. Journal of Experimental Zoology, vol. 270, n. 5, p. 432-444. http://dx.doi.org/10.1002/jez.1402700504

GIRONDOT, M., FOUILLET, H. and PIEAU, C., 1998. Feminizing turtle embryos as a conservation toil. Conservation Biology, vol. 12, n. 2, p. 353-362. http://dx.doi.org/10.1046/j.15231739.1998.96382.x

GODLEY, BJ., BRODERICK, AC. and HAYS, GC., 2001a. Nesting of green turtles (Chelonia mydas) at Ascension Island, South Atlantic. Biological Conservation, vol. 97, n. 2, p. 151 -1 58.

GODLEY, BJ., BRODERICK, AC. and MROSOVSKY, N., 2001. Estimating hatchling sex ratios of loggerhead turtles in Cyprus from incubation durations. Marine Ecology Progress Series, vol. 210, p. 195-201. http://dx.doi.org/10.3354/meps210195

HOSMER, D.W. and LEMERSHOW, S., 2000. Applied Logistic Regression. New York: John Wiley. http://dx.doi. org/10.1002/0471722146

LUBIANA, A. and FERREIRA JÚNIOR, PD., 2009. Pivotal temperature and sexual dimorphism of Podocnemis expansa hatchlings (Testudines: Podocnemididae) from Bananal Island, Brazil. Revista Brasileira de Zoologia, vol. 26, n. 3, p. 527-533.

MALVASIO, A., SOUZA, AM., FERREIRA JÚNIOR, PD., REIS, ES. and SAMPAIO, FAA., 2002a. Temperatura de incubação dos ovos e granulometria dos sedimentos das covas relacionadas à determinação sexual em Podocnemis expansa (Schweigger, 1812) e P. unifilis (Troschel, 1848) (Testudines, Pelomedusidae). Publicações Avulsas do Instituto Pau Brasil de História Natural, vol. 5, n. 1, p. 11-25.

MALVASIO, A., SOUZA, AM., SCHLENNZ, E., SALERA JÚNIOR, G. and SAMPAIO, FAA., 2002b. Morfologia dos órgãos reprodutores de recém-eclodidos de Podocnemis expansa (Schweigger, 1812) e P. unifilis (Troschel, 1848) (Testudines, Pelomedusidae). Publicações Avulsas do Instituto Pau Brasil de História Natural, vol. 5, n. 1, p. 27-37.
-, 2005. Influência da manipulação dos ovos no sucesso das eclosões e no padrão normal de escutelação do casco em Podocnemis expansa (Schweigger, 1812) e P. unifilis (Troschel, 1848) (Testudines, Pelomedusidae). Publicações Avulsas do Instituto Pau Brasil de História Natural, vol 8-9, n. 1, p. 39-52.

MARCOVALDI, MA., GODFREY, MH. and MROSOVSKY, N., 1997. Estimating sex ratios of loggerhead turtles in Brazil from pivotal incubation durations. Canadian Journal of Zoology, vol. 75, n. 5, p. 755-770. http://dx.doi.org/10.1139/z97-097

MILTON, SL., SCHULMAN, AA. and LUTZ, PL., 1997. The effect of beach nourishment with aragonite versus silicate sand on beach temperature and loggerhead sea turtle nesting success. Journal of Coastal Research, vol. 13, n. 3, p. 904-915.

MITCHELL, C. and QUIÑONES, L., 1994. Manejo y conservacion de la taricaya (Podocnemis unifilis) en la Reserva de Biofera del Manu, Madre de Dios. Boletin de Lima, vol. 16, p. 425-436.

MORREALE, SJ., SPOTILA, JR. and STANDORA, EA. 1982. Temperature dependent sex determination: current pratices threaten conservation of sea turtles. Science, vol. 216, n. 4551, p. 12451247. PMid:7079758. http://dx.doi.org/10.1126/science.7079758

MROSOVSKY, N., BAPTISTOTTE, C. and GODFREY, MH., 1999. Validation of incubation duration as an index of the sex ratio of hatchling sea turtles. Canadian Journal of Zoology, vol. 77, n. 5, p. 831-835. http://dx.doi.org/10.1139/z99-039

MROSOVSKY, N., BASS, A., CORLISS, LA., RICHARDSON, JI. and RICHARDSON, TH., 1992. Pivotal and beach temperatures for hawksbill turtles nesting in Antigua. Canadian Journal of Zoology, vol. 70, n. 10, p. 1920-1925. http://dx.doi.org/10.1139/z92-261

MROSOVSKY, N., HOPKINS-MURPHY, SR. and RICHARDSON, JI., 1984. Sex ratio of sea turtles: seasonal changes. Science, vol. 225, n. 4663, p. 739-740. PMid:17810293. http://dx.doi. org/10.1126/science.225.4663.739

MROSOVSKY, N., KAMEL, SJ., DIEZ, CE. and VAN DAM, RP., 2009. Methods of estimating natural sex ratios of sea turtles from incubation temperatures and laboratory data. Endangered Species Research, vol. 8, n. 3, p. 147-155. http://dx.doi.org/10.3354/ esr00200

NARO-MACIEL, E., MROSOVSKY, N. and MARCOVALDI, MA., 1999. Thermal profiles of sea turtle hatcheries and nesting areas at Praia do Forte, Brazil. Chelonian Conservation and Biology, vol. 3, p. 407-413.

PEZZUTI, JCB. and VOGT, RC., 1999. Nesting ecology of Podocnemis sextuberculata (Testudines, Pelomedusidae) in the Japurá River, Amazonas, Brazil. Chelonian Conservation and Biology, vol. 3, p. 419-424.

PIEAU, C. and DORIZZI, M. 1981. Determination of temperature sensitive stage for sexual differentiation of the gonads in embryos of the turtle, Emys orbicularis. Journal of Morphology, vol. 170, n. 3, p. 373-382. http://dx.doi.org/10.1002/jmor.1051700308

PRITCHARD, PCH. and TREBBAU, P., 1984. The turtles of Venezuela. Caracas: Society for the Study of Amphibians and Reptiles.

RUEDA-ALMONACID, JV., CARR, JL., MITTERMEIER, RA., RODRÍGUEZ-MAHECHA, JV., MAST, RB., VOGT, RC., RHODIN, AGJ., OSSA-VELÁSQUEZ, J., RUEDA, JN. and MITTERMEIER, CG., 2007. Las tortugas y los cocodrilianos de los países andinos del trópico. Bogotá: Conservación Internacional. 
SALERA JÚNIOR, G., MALVASIO, A. and PORTELINHA, TCG., 2009. Avaliação de padrão irregular dos escudos do casco em Podocnemis expansa e Podocnemis unifilis (Testudines, Podocnemididae). Acta Amazonica, vol. 39, n. 2, p. 431-438.

VALENZUELA, N., 2001. Constant, shift, and natural temperatures effects on sex determination in Podocnemis expansa turtles. Ecology, vol. 82, n. 11, p. 3010-3024.

-, Evolution and maintenance of temperature-dependent sex determination. In VALENZUELA, N. and LANCE, VA. (Eds). Temperature dependent sex determination in vertebrates. Washington: Smithsonian Books. p. 131-147.

VALENZUELA, N. and LANCE, VA., 2004. Temperature dependent sex determination in vertebrates. Washington: Smithsonian Books
VALENZUELA, N., BOTERO, R. and MARTÍNEZ, E., 1997. Field study of sex determination in Podocnemis expansa from Colombian Amazonian. Herpetologica, vol. 53, p. 390-398.

TUTTLE, J. and ROSTAL, D., 2010. Effects of nest relocation on nest temperature and embryonic development of Loggerhead Sea Turtles (Caretta caretta). Chelonian Conservation and Biology, vol. 9, n. 1, p. 1-7. http://dx.doi.org/10.2744/CCB-0769.1

YNTEMA, CL. and MROSOVSKY, N., 1982. Critical periods and pivotal temperatures for sexual differentiation loggerhead sea turtles. Canadian Journal of Zoology, vol. 60, n. 5, p. 1012-1016. http://dx.doi.org/10.1139/z82-141 